\title{
Enhancement of Push-Pull Properties of Pentafulvene and Pentafulvalene Derivatives by Protonation at Carbon
}

\author{
Sophie Haberland, ${ }^{[a]}$ Aaron D. Finke, ${ }^{[a]}$ Nicolas Kerisit, ${ }^{[a]}$ Claudine Katan, ${ }^{[b]}$ Yann Trolez, ${ }^{[b]}$ Przemyslaw \\ Gawel, ${ }^{[a]}$ Ivo Leito, ${ }^{[c]}$ Märt Lõkov, ${ }^{[c]}$ Robert Järviste, ${ }^{[c]}$ Karl Kaupmees, ${ }^{[c]}$ Nils Trapp, ${ }^{[a]}$ Laurent \\ Ruhlmann, ${ }^{[\mathrm{d}]}$ Corinne Boudon, ${ }^{[\mathrm{d}]}$ Daniel Himmel, ${ }^{[\mathrm{e}]}$ and François Diederich ${ }^{*[\mathrm{a}]}$
}

Dedication ((optional))

\begin{abstract}
We report visible color changes and new intense, bathochromically shifted bands in absorption spectra that reach into the near-infrared region (up to $862 \mathrm{~nm}$ ) upon protonation of nine pentafulvene and expanded pentafulvalene derivatives. This phenomenon can only be explained by the formation of carbocations with highly delocalized charges. Solution $\mathrm{p} K_{\mathrm{a}}$ values in organic solvents were determined, making use of the method of relative basicity measurements. All seven 6-phenylpentafulvenes are weak bases, and $\mathrm{p} K_{\mathrm{a}}$ values range from 0.92 to 10.29 in acetonitrile and from 1.77 to 6.46 in 1,2-dichloroethane. For the 6-phenylfulvenes with varying para-substituents on the phenyl ring, $\mathrm{p} K_{\mathrm{a}}$ values correlate well with the Hammett parameters $\sigma_{\text {para. }}$. Furthermore, for most compounds, electrochemical reduction is significantly facilitated by protonation. Extensive theoretical and NMR studies strongly support the postulated protonation at carbon.
\end{abstract}

\section{Introduction}

Fulvenes are $\pi$-conjugated hydrocarbons composed of an oddmembered ring with one exocyclic, cross-conjugated $\mathrm{C}=\mathrm{C}$ double bond. If this double bond is directly cross-conjugated to another odd-membered $\pi$-conjugated ring, the resulting compounds are called fulvalenes. ${ }^{[1]}$ The first to mention color changes of fulvene derivatives induced by the addition of acids were Prinzbach et al.

[a] S. Haberland, Dr. A. D. Finke, Dr. N. Kerisit, Dr. P. Gawel, Dr. N. Trapp, Prof. F. Diederich

Laboratorium für Organische Chemie

ETH Zurich

Vladimir-Prelog-Weg 3, 8093 Zurich (Switzerland)

E-mail: diederich@org.chem.ethz.ch

[b] Institut des Sciences Chimiques de Rennes, UMR 6226, CNRS, Ecole Nationale Supérieure de Chimie de Rennes, Université de Rennes 1, INSA de Rennes, 35042 Rennes (France)

[c] Prof. I. Leito, M. Lõkov, R. Järviste, Dr. K. Kaupmees Institute of Chemistry

University of Tartu

Ravila 14a, Str, 50411, Tartu (Estonia)

[d] Prof. L. Ruhlmann, Prof. C. Boudon

Laboratoire d'Electrochimie et de Chimie Physique du Corps Solide, Institut de Chimie-UMR 7177, CNRS, Université de Strasbourg,

4 rue Blaise Pascal, 67081 Strasbourg Cedex (France)

[e] Dr. D. Himmel

Institute for Inorganic and Analytical Chemistry, Freiburger

Materialforschungszentrum FMF and Freiburg Institute for Advanced

Studies (FRIAS)

Albert-Ludwigs-Universität Freiburg

Albertstr. 21, 79104 Freiburg (Germany)

Supporting information for this article is given via $\mathrm{xxx}$. in 1966. ${ }^{[2]}$ They showed that protonation of a sesquifulvalene (five and seven-membered $\pi$-conjugated rings connected by a crossconjugated $\mathrm{C}=\mathrm{C}$ bond) at carbon gave a stable carbocation with consistent NMR signals. In the early 1980s, Neuenschwander and coworkers described the cationic polymerization of 6alkyl(penta)fulvenes. ${ }^{[3]}$ They suggested that protonation takes place at one of the endocyclic carbon atoms C2 or C5 (for numbering, see Figure 1) based on the obtained polymer structures, mechanistic studies, as well as theoretical calculations. However, Olah et al. were the first to report systematic studies of a variety of fulvenium ions that were prepared by protonation in super-acidic media. ${ }^{[4]}$ Based mainly on ${ }^{1} \mathrm{H}$ and ${ }^{13} \mathrm{C}$ NMR studies, they showed that protonation occurs exclusively at the C2 and C5 positions.

Protonated fulvenium ions have also been the subject of theoretical calculations, ${ }^{[5]}$ and electronic absorption spectroscopy in neon matrices at $6 \mathrm{~K}$, paired with calculations, suggested isomerization between protonated fulvenium ions and protonated benzene. ${ }^{[6]}$ Kende and Izzo proposed C-protonation of sesquifulvalenes with a three- and a five-membered ring. ${ }^{[7]}$ It seems that over time, after Prinzbach's early findings, changes in optical properties upon protonation of fulvenes and fulvalenes,

Figure 1. Structures of 6-phenylfulvenes 1-7, [3]cumulene-expanded fulvalene 8 , and fulvene derivative $( \pm)-9$. The shown arbitrary numbering of carbon atoms

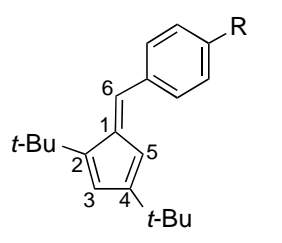

$$
\begin{array}{ll}
1 \mathrm{R}=\mathrm{NMe}_{2} \\
2 \mathrm{R}=\mathrm{OMe}^{2} \\
3 \mathrm{R}=\mathrm{Me} \\
4 \mathrm{R}=\mathrm{H} \\
5 \mathrm{R}=\mathrm{Cl} \\
6 \mathrm{R}=\mathrm{CN} \\
7 \mathrm{R}=\mathrm{NO}_{2}
\end{array}
$$<smiles>C(=C1C(c2ccccc2)=C(c2ccccc2)C(c2ccccc2)=C1c1ccccc1)C1=C(c2ccccc2)C(c2ccccc2)=C(c2ccccc2)C1c1ccccc1</smiles>

8
$( \pm)-9$

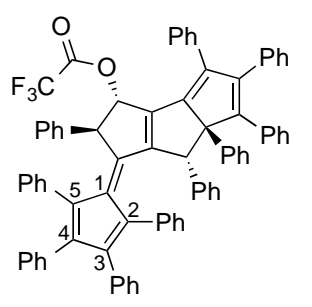

in 1-8 is used in further discussions. For compound $( \pm)-9$, the IUPAC numbering is given.

have largely been forgotten.

It is known that protonation of certain donor- $\pi$-bridge-acceptor (D- $\pi-A)$ molecules can reinforce their push-pull character. ${ }^{[8]}$ 
However, this is only the case if protonation takes place at the electron accepting moiety of the molecule, thus, making it an even stronger acceptor. At the same time, it is rare that the acceptor moiety is more basic than the donor moiety due to its intrinsic lack of electrons.

Our study demonstrates the enhancement of $\pi$-conjugated pushpull effects by protonation at a carbon atom. It is a wellestablished practice for push-pull molecules with basic amines as electron-donors to subject them to acidic conditions to test whether the longest-wavelength electronic absorption band belongs to the intramolecular charge-transfer (ICT) transition. ${ }^{[9]}$ If this is the case, this band is quenched and a higher-energy band representing the protonated ammonium chromophore appears. Accordingly, we expected a solution of compound 1 (Figure 1) to lose its color upon protonation. To our great surprise, addition of trifluoroacetic acid (TFA) to an initially orange solution of $\mathbf{1}$ in $\mathrm{CH}_{2} \mathrm{Cl}_{2}$ did not lead to color quenching but instead the solution turned deep blue. This effect is fully reversible upon neutralization with $\mathrm{NEt}_{3}$. The same effect was observed in other chlorinated solvents, such as $\mathrm{CHCl}_{3}$ and 1,2-dichloroethane (1,2-DCE), as well as in acetonitrile.

With the objective of understanding this phenomenon, we synthesized a series of 6-phenylfulvenes 1-7 with different parasubstituents on the phenyl rings (Figure 1) and investigated their protonation behavior. We installed tert-butyl groups at the endocyclic positions in order to simplify NMR analysis, prevent polymerization, and enhance solubility. Interestingly, we also found that fulvalene 8 and the complex pentafulvene-derived chromophore ( \pm ) $\mathbf{- 9}$ (Figure 1) show an even stronger bathochromic shift of their main electronic absorption band upon acidification.

This paper reports the synthesis of $\mathbf{1}$ to $( \pm)-\mathbf{9}$, the experimental $\mathrm{p} K_{\mathrm{a}}$ values of these chromophores in acetonitrile and 1,2-DCE, as well as NMR, UV/Vis, and electrochemical studies on their protonation behavior. The experimental findings are rationalized with the help of DFT and TD-DFT calculations, by comparing Gibbs free energies of species protonated at different sites and calculated and measured optical properties.

\section{Results and Discussion}

\section{Synthesis}

The synthesis of 6-phenylfulvenes 1-7 takes advantage of the unusually high acidity of cyclopentadienes (CPDs, p $K_{a} \approx 16$ ) compared to other hydrocarbons. ${ }^{[10]}$ It is known that $1,2,3,4$ tetraphenylcyclopenta-1,3-diene undergoes condensation with arylaldehydes in the presence of sodium methoxide in methanol at reflux. ${ }^{[11]}$ The same method was used herein with 1,3-di-tertbutylcyclopentadiene ${ }^{10^{[12]}}$ and para-substituted benzaldehydes 11-17 (Scheme 1A). (E)-Configured fulvenes 2-7 were isolated in $40-78 \%$ yields as bright orange solids. ${ }^{[13]}$ Reaction times increase from 7 hours (for $\mathrm{R}=\mathrm{NO}_{2}$ ) to five days (for $\mathrm{R}=\mathrm{OMe}$ ) with increasing electron-donating strength of the para-substituent on the benzaldehyde. This general protocol did not work well with 4-( $N, N$-dimethylamino)benzaldehyde 11 , presumably due to its much lower electrophilicity. We instead treated a solution of $\mathbf{1 0}$ with $n$-butyl lithium at $-78^{\circ} \mathrm{C}$ followed by addition of aldehyde 11 , which afforded 1 as a bright orange solid in $27 \%$ yield.

The synthesis of both 8 and ( \pm )-9 (Scheme 1B) started from alkyne 18 , which was prepared from $19^{[14]}$ by addition of lithiated trimethylsilylacetylene and successive methylation with dimethyl sulfate according to literature procedures (Section S2 in the Supporting Information (SI)). In both cases, the in situ formed acetylide of 18 reacts with electrophiles, cyclopentadienone 19 or tropylium tetrafluoroborate, to give 20 and $\mathbf{2 1}$, respectively, in good yields. The structure of compound 21 was confirmed by single-crystal X-ray diffraction (Section S10 in the SI). Alcohol 20 was subsequently subjected to reductive elimination with tin(II) chloride in acidic ethereal solution, which is a commonly used method for cumulene synthesis. ${ }^{[15]}$ After 2.5 h, pure cumulene 8 was filtered from the reaction mixture as a dark brown solid.

Treatment of $\mathbf{2 1}$ with an excess of TFA led to the unexpected formation of fulvene derivative ( \pm ) -9 in $33 \%$ yield (for a discussion of the possible mechanism, see Section S4 in the SI).

\section{X-ray Crystal Structures}

The structures of 6-phenylfulvenes 1 and 6 , intermediate 21, extended fulvalene $\mathbf{8}$, and fulvene $( \pm)-9$ were determined by single-crystal X-ray diffraction (Figure 2, Section S10 in the SI).

Monoclinic crystals (space group $C 1 c 1$ (no. 9)) of 1 were obtained by slow evaporation of $\mathrm{CH}_{2} \mathrm{Cl}_{2}$. The two rings of the molecule are twisted by $21^{\circ}$.

Monoclinic crystals (space group $P 2_{1} / c$ (no. 14)) of 8 were grown by layering $\mathrm{MeOH}$ onto a fluorobenzene solution. The unit cell accommodates one half of centrosymmetric 8 . At $100 \mathrm{~K}$, bond length alternation $(B L A)^{[16]}$ of the cumulenic bonds was determined to be $0.099 \AA$. This value is a little larger than expected, based on comparison with other symmetric [3]cumulenes. ${ }^{[17]}$ This could be attributed to the strong $\pi$ conjugation between the terminal cyclopenta1,3-diene rings and

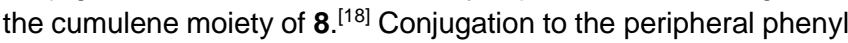
rings is hindered since they are twisted by $45^{\circ}$ to $61^{\circ}$ relative to the planar extended fulvalene core. The intramolecular center-tocenter distance between phenyl rings attached to different cyclopenta-1,3-diene rings (Figure 2) was measured to be $4.7 \AA$, reflecting only weak aromatic $\pi$ - $\pi$-stacking interactions. ${ }^{[19]}$

Brown crystals (monoclinic, space group $P 2_{1} / n$ (no. 14)) suitable for X-ray diffraction were obtained by slow diffusion of pentane into an ethyl acetate solution of compound $( \pm)-9$ at $5^{\circ} \mathrm{C}$. Only the displayed stereoisomer $(2 R, 3 S, 6 \mathrm{a} R, 7 R)-9$ was present in the measured crystal. Similar to 8 , phenyl groups are twisted by $38^{\circ}$ to $64^{\circ}$ out of the plane of the cyclopenta-1,3-diene rings to which they are attached. 
A<smiles>[R]c1ccc(/C=C2\C=C(C(C)(C)C)C=C2C(C)(C)C)cc1</smiles>

10
$11 \mathrm{1} R=\mathrm{NMe}_{2}(27 \%)$

$12 \mathrm{2} \mathrm{R}=\mathrm{OMe}(60 \%)$

13 - $3 \mathrm{R}=\mathrm{Me}(74 \%)$

$144 \mathrm{R}=\mathrm{H}(78 \%)$

$150 \mathrm{R}=\mathrm{Cl}(74 \%)$

$16 \mathrm{R}=\mathrm{CN}(76 \%)$

$177 \mathrm{R}=\mathrm{NO}_{2}(40 \%)$

B<smiles>C#CC1(OC)C(c2ccccc2)=C(c2ccccc2)C(c2ccccc2)=C1c1ccccc1</smiles>

18
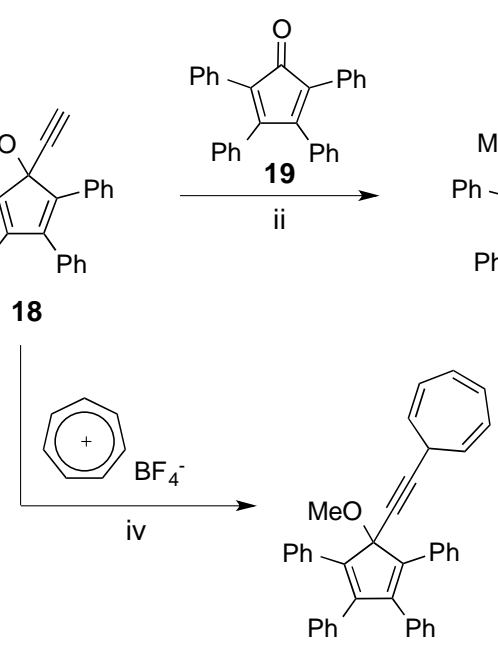

$21(81 \%)$<smiles>COC(C#CC1(c2ccccc2)C(c2ccccc2)=C(c2ccccc2)C(c2ccccc2)=C1c1ccccc1)(c1ccccc1)c1ccccc1</smiles>

$20(71 \%)$<smiles>c1ccc(-c2c(-c3ccccc3)c(-c3ccccc3)c(-c3ccccc3)c(-c3ccccc3)c2-c2ccccc2)cc1</smiles>

$8(27 \%)$

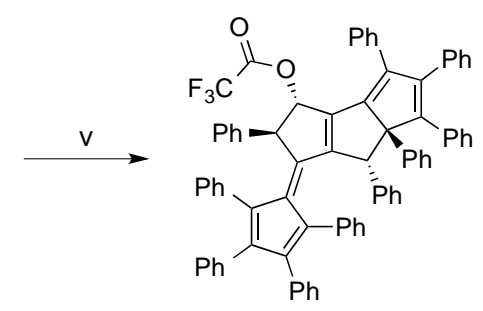

$( \pm)-9$

Scheme 1. A) Synthesis of 6-phenylfulvenes 1-7. i) $n$-BuLi, THF for 1; NaOMe, MeOH for 2-7; B) Synthesis of compounds 8 and ( \pm )-9 from alkyne 18. ii) $n$-BuLi, THF, $-78^{\circ} \mathrm{C}$ to $25^{\circ} \mathrm{C}, 20 \mathrm{~h}$; iii) $\mathrm{SnCl}_{2}, \mathrm{HCl}, \mathrm{Et}_{2} \mathrm{O}, 25^{\circ} \mathrm{C}, 2.5 \mathrm{~h}$; iv) EtMgBr, THF, $-78^{\circ} \mathrm{C}$ to $25^{\circ} \mathrm{C}, 4 \mathrm{~h}$; v) $\mathrm{TFA} \mathrm{CH}_{2} \mathrm{Cl}_{2}, 25^{\circ} \mathrm{C}, 1 \mathrm{~h}$. THF = tetrahydrofuran; TFA = trifluoroacetic acid.

\section{Discovery of Unusal Protonations by Electronic Absorption Spectroscopy}

We recorded the UV/Vis spectra of compounds 1-8 in both $\mathrm{CH}_{2} \mathrm{Cl}_{2}$ and 1,2-DCE and of compound $( \pm)-9$ in $\mathrm{CH}_{2} \mathrm{Cl}_{2}$. The spectra were also measured upon addition of acid (TFA). For all compounds 1-( \pm$)-9$, the spectra of the neutral compound could be fully restored by addition of base $\left(\mathrm{NEt}_{3}\right)$ to the acidified solution. The spectra of 1 are shown in Figure 3. In 1,2-DCE, the longestwavelength absorption band of a yellow-colored, neutral solution of 1 appears at $\lambda_{\max }=398 \mathrm{~nm}(3.12 \mathrm{eV})$, which we attribute to an ICT between the amine donor and the fulvene acceptor. Upon acidification with TFA, the solution color changes in a remarkable way (Figure 3, top) to deep blue and in presence of around 20 equiv. of the acid, when protonation is complete the spectrum features a broad, longest-wavelength band at $\lambda_{\max }=593 \mathrm{~nm}(2.09$ eV) (Figure 3, middle). ${ }^{[20]}$ The initial strong band of neutral 1 at $398 \mathrm{~nm}$ has nearly disappeared, and a new, higher-energy band arises at $309 \mathrm{~nm}(4.01 \mathrm{eV})$, which is very similar to that of compound 4 with an unsubstituted phenyl ring (experimental: $\lambda_{\max }$ $=307 \mathrm{~nm}, 4.04 \mathrm{eV}$ ). As shown in detail in the following sections, the longest-wavelength band at $593 \mathrm{~nm}$ reflects a species protonated at carbon, whereas the band at $309 \mathrm{~nm}$ can be assigned to an $\mathrm{N}$-protonated species. Upon addition of triethylamine, the spectrum of the neutral solution is fully restored apart from a small decrease in intensity attributed to the diluting effect of acid and base addition (see Figure 3, middle). Upon addition of an excess of even stronger acids to 1 , such as $\mathrm{HBF}_{4}$ or $\mathrm{MeSO}_{3} \mathrm{H}$, the solution turns yellow. In the presence of $\mathrm{HBF}_{4}$, a longest-wavelength band at $\lambda_{\max }=444 \mathrm{~nm}(2.79 \mathrm{eV})$ appears, indicative of yet a new species formation (see Figure S32 in the SI) Below, we provide evidence for the formation of a dicationic species, protonated at $\mathrm{N}$ and $\mathrm{C}$.

In the absence of acid, compounds 2-7 show absorption bands with longest-wavelength maxima between $\lambda_{\max }=307-333 \mathrm{~nm}$ (3.72-4.04 eV) (see Figures S33-S38 in the SI). These values do not correlate well with the Hammett parameter $\sigma_{\text {para }}$ of the parasubstituents at the phenyl rings $\left(r^{2}=0.45\right)$. Upon protonation at carbon (see below), 6-phenylfulvenes 2-7 all show a significant bathochromic shift of the longest-wavelength absorption band which appears between $\lambda_{\max }=535(2,2.32 \mathrm{eV})$ and $449 \mathrm{~nm}(\mathbf{7}$, $2.76 \mathrm{eV}$; see Figures S33-S38 in the SI). After protonation, a moderately good correlation $\left(r^{2}=0.87\right)$ of the absorption maxima with the Hammett $\sigma_{\text {para-parameter is now observed for fulvenes }}$ 1-7 (Figure 4).

Neutral solutions of expanded fulvalene 8 in $\mathrm{CH}_{2} \mathrm{Cl}_{2}$ are deep red and turn dark grey after addition of TFA (Figure S39 in the SI). In the absence of acid, the longest-wavelength absorption of 8 appears at $\lambda_{\max }=505 \mathrm{~nm}(2.45 \mathrm{eV})$, whereas in the presence of acid it shifts bathochromically to $731 \mathrm{~nm}(1.70 \mathrm{eV})$, reflecting protonation at carbon. 
A

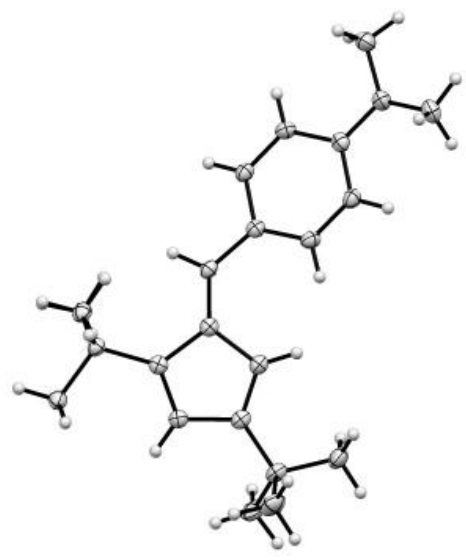

B

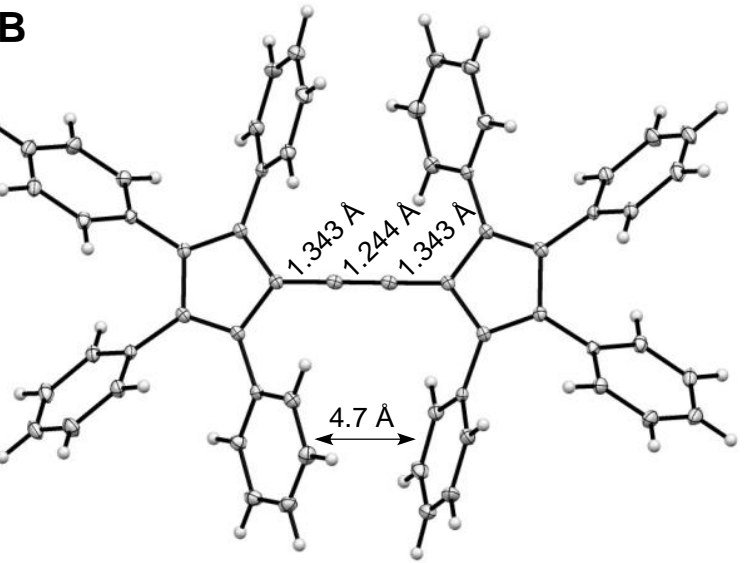

C

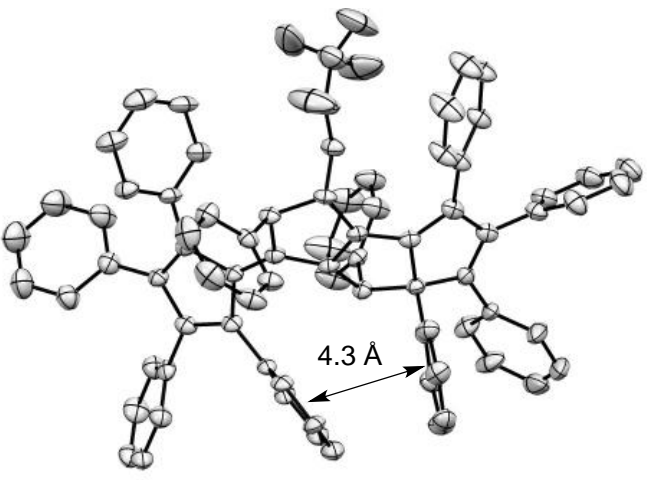

Figure 2. Crystal structures of A) 1; B) 8, and C) $(2 R, 3 S, 6 a R, 7 R)-9 . T=100 \mathrm{~K}$. Thermal ellipsoids at $50 \%$ probability, for $\mathbf{9}$, hydrogen atoms are omitted for clarity.

Compound ( \pm )-9 was isolated as a black solid. For a few hours and only at ambient temperature, neutral solutions of $( \pm)-9$ in $\mathrm{CH}_{2} \mathrm{Cl}_{2}$ appear deep pink. The longest-wavelength absorption band accordingly is located at $\lambda_{\max }=530 \mathrm{~nm}(2.34 \mathrm{eV}$ ) (Figure 3 , bottom). After addition of an excess of TFA, this band flattens and an intense band in the near-infrared region (NIR) arises at $\lambda_{\max }=$ $862 \mathrm{~nm}(1.44 \mathrm{eV})$.

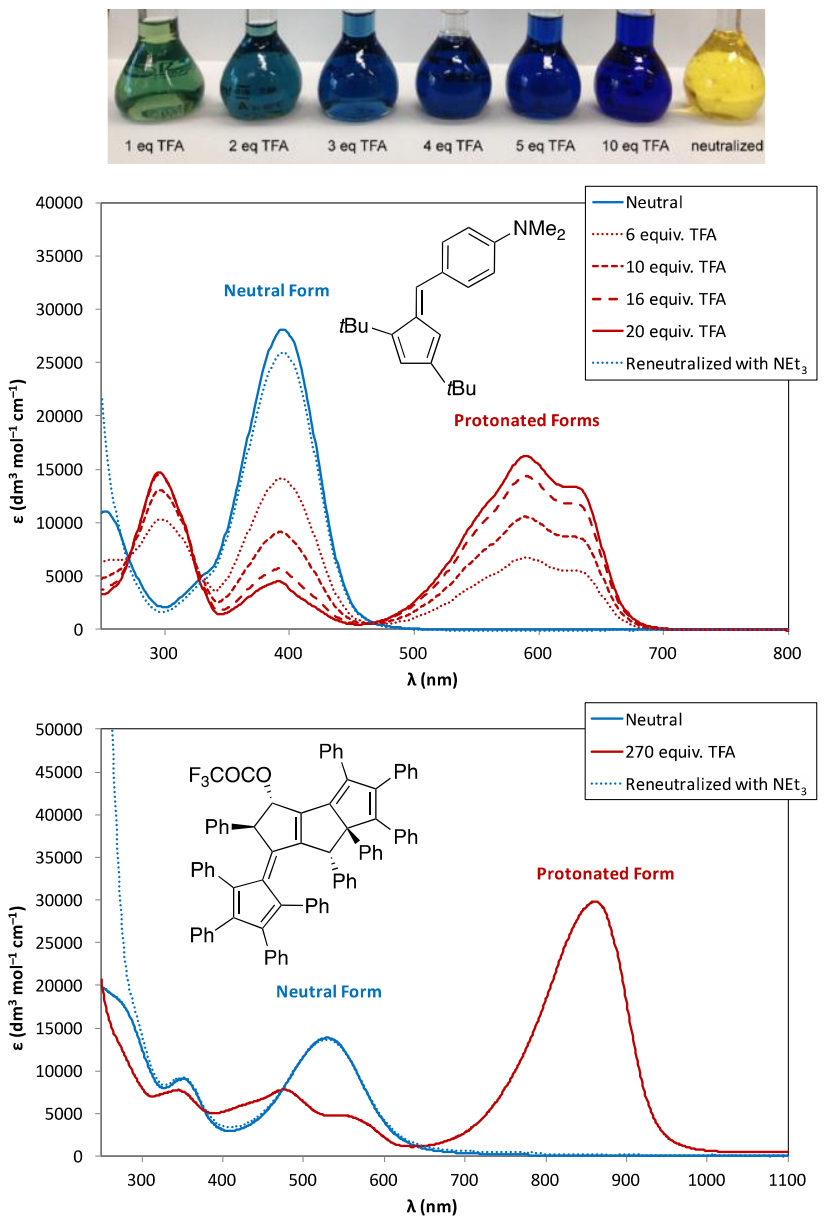

Figure 3. Top: Acidified solutions of $\mathbf{1}$ in $\mathrm{CH}_{2} \mathrm{Cl}_{2}$. Middle: UV/Vis spectra of $\mathbf{1}$ in $\mathrm{CH}_{2} \mathrm{Cl}_{2}$, neutral, acidified, and reneutralized with excess $\mathrm{NEt}_{3}$. Bottom: UV/Vis spectra of $( \pm)-9$ in $\mathrm{CH}_{2} \mathrm{Cl}_{2}$ neutral, acidified, ${ }^{[20]}$ and reneutralized with excess $\mathrm{NEt}_{3}$.

Neutral ( \pm )-9 has limited stability in solution. After a few hours in $\mathrm{CH}_{2} \mathrm{Cl}_{2}$, the solutions turn red, which also occurs immediately upon heating to $40^{\circ} \mathrm{C}$.

The stability of the protonated forms of the 6-phenylfulvenes in $\mathrm{CDCl}_{3}$ at room temperature was monitored for compounds $\mathbf{2}$ and 3 by ${ }^{1} \mathrm{H}$ NMR spectroscopy. After addition of 100 equiv. of TFA, ${ }^{1} \mathrm{H}$ NMR spectra were measured every $24 \mathrm{~h}$ over the course of 3 days showing no decomposition for both cations (see Figures S26 and S29 in the SI). ${ }^{[20]}$

\section{Plausible Protonation Sites}

We expected the nitrogen atom to be the most basic site of 6 phenylfulvene 1. Protonation at nitrogen, leading to 1a (Figure 5), diminishes the push-pull effect by eliminating the ability of the amine lone pair to take part in $\pi$-conjugation. Hence, it does not explain the bathochromic shift of the longest-wavelength absorption band that leads to the intense blue color. Based on 


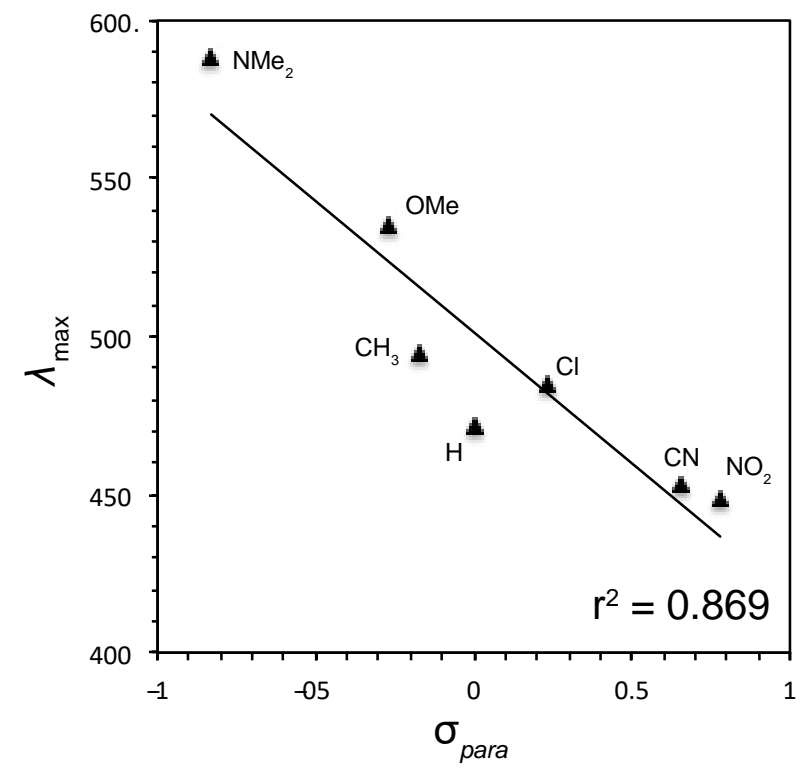

Figure 4. Maximum absorption wavelengths $\lambda_{\max }$ of 6 -phenylfulvenes 1-7 in $\mathrm{CH}_{2} \mathrm{Cl}_{2}$ after addition of TFA, plotted against the corresponding Hammett parameters $\sigma_{\text {para }}$ (taken from [21]).

previous reports on fulvene protonation, we suggest protonation to occur at C5 leading to $\mathbf{1 b} .^{[4,7]}$ As a result of the positive charge at $\mathbf{C} 4$, the push-pull character of $\mathbf{1} \mathbf{b}$ is even more pronounced than in 1. This can be illustrated by analysis of its resonance structure 1e, which is an iminium ion, with a highly delocalized charge. However, protonation at both sites, nitrogen and C5 leads to a structure (1d) where the push-pull effect is almost canceled out. Thus, we propose, that upon addition of excess TFA, there is tautomerism only between $\mathbf{1 a}$ and $\mathbf{1 b}$. Similar considerations can be made for compounds 2-7.

For extended fulvalene $\mathbf{8}$, we suggest protonation at C2 (for numbering, see Figure 1), which produces the species with the largest number of reasonable resonance structures.<smiles>CNc1ccc(C=C2C=C(C(C)(C)C)C=C2C(C)(C)C)cc1</smiles>
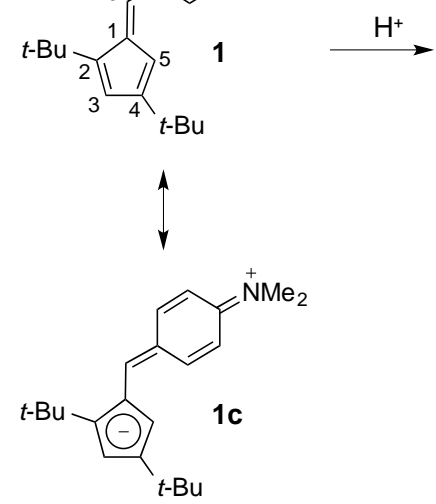

Figure 5. Postulated Lewis structures of protonated 1.
For compound $( \pm)-9$, the situation is more complex (Figure 6). Protonation is most plausible to take place at (i) the ester (( \pm ) $-9 \mathbf{a})$, (ii) one end of the $\pi$-conjugated system $(( \pm)-9 b$ and $( \pm)-9 c)$, or at (iii) the other end $(( \pm)-9 d)$. When protonation takes place at carbon, cations with highly delocalized charges are formed. Protonated ( \pm )-9b and $( \pm)-9 c$ can be presented as four resonance structures where the positive charge could to some extent (due to nonplanarity) be delocalized into a phenyl group. In contrast, ( \pm )9d has only three reasonable resonance structures with charges adjacent to a phenyl group. Additionally, for $( \pm)$-9d one of the resonance structures is formally antiaromatic. Figure 6 shows the three diastereoisomers $( \pm)-9 b,( \pm)-9 c$, and $( \pm)-9 d$ that are believed to be sterically favored.

These hypotheses are cacked in the following based on extensive theoretical and NMR studies.

\section{NMR and EPR Studies}

In order to understand the equilibrium between $\mathbf{1}$ and its protonated species $\mathbf{1 a}$ and $\mathbf{1 b}$, we conducted ${ }^{1} \mathrm{H}$ NMR titrations of 1 with TFA in $\mathrm{CH}_{2} \mathrm{Cl}_{2}$ (Figure 7). Addition of one and two equiv. of TFA mainly leads to spectra at fast exchange between species with shifts and integrals that fit the structure of the $\mathrm{N}$-protonated species 1a. The aromatic signals at $6.7 \mathrm{ppm}$ and $7.5 \mathrm{ppm}$ move closer together, indicating protonation at nitrogen. This is because upon protonation of the amine, the $\pi$-donor effect vanishes. Thus, the ortho- $\left(3^{\prime}, 5^{\prime}\right)$ and meta-positions $\left(2^{\prime}, 6^{\prime}\right)$ relative to the amino group become electronically less distinguished. However, upon addition of more TFA, we see slow exchange between 1a and another species. In the presence of five equiv. of TFA, the spectrum fits the structure of the C5-protonated form $\mathbf{1 b}$. The signal of the methylene group for $\mathbf{1 b}$ can be found at $3.8 \mathrm{ppm}$ as a singlet (Figure 7, yellow background). This result is comparable to earlier findings about fulvene protonation where methylene groups give signals at 4.2 to $4.8 \mathrm{ppm} \cdot{ }^{[4,7]}$ Upon addition of deuterated TFA, the methylene singlet vanishes completely, which shows that both $\mathrm{C} 5$ protons are exchanged by deuterium. Thus, we propose, that in the presence of four equiv. of TFA, $\mathrm{N}$ protonated 1a and C5-protonated $\mathbf{1 b}$ coexist. Addition of an excess of TFA leads to a shift of the equilibrium towards the $C$ protonated form $\mathbf{1 b} .^{[30]}$
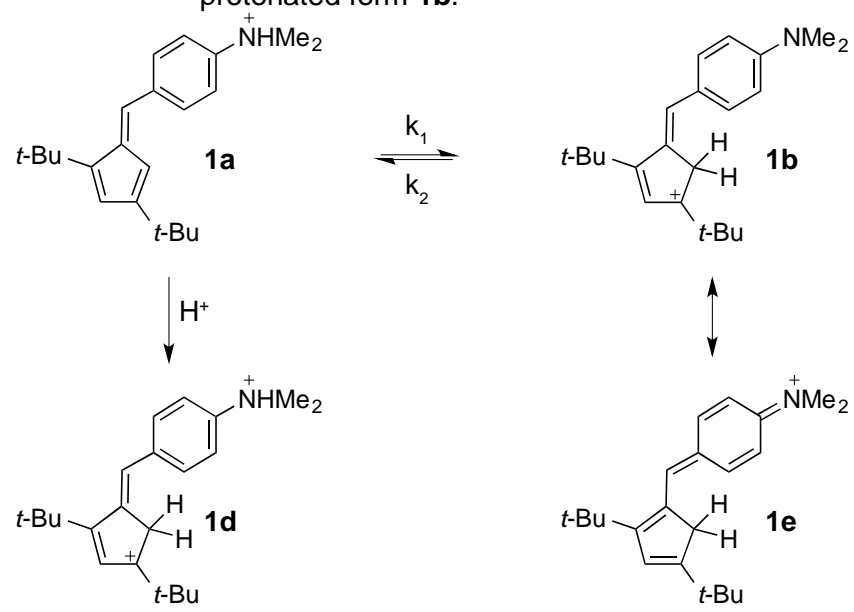


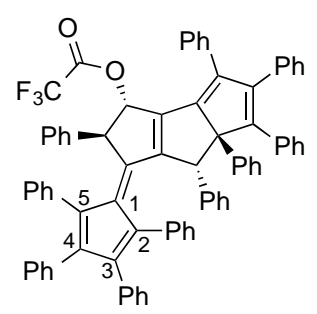

$( \pm)-9$<smiles>O=C(OC1C2=C(c3ccccc3)C(c3ccccc3)C(c3ccccc3)C2=C(c2ccccc2)C1c1ccccc1)C(F)(F)F</smiles>

$( \pm)-9 a$<smiles>O=C(O[C@H]1C2=C(C(=C3C(c4ccccc4)=C(c4ccccc4)[C@H](c4ccccc4)C3c3ccccc3)C(c3ccccc3)=C2c2ccccc2)[C@H](c2ccccc2)C1c1ccccc1)C(F)(F)F</smiles>

$( \pm)-9 b$<smiles>O=C(O[C@H]1C2=C(c3ccccc3)[C@@H](c3ccccc3)C(C3=C(c4ccccc4)C(c4ccccc4)=C(c4ccccc4)[C@@H]3c3ccccc3)=C2C(c2ccccc2)=C1c1ccccc1)C(F)(F)F</smiles>

$( \pm)-9 c$<smiles>O=C(O[C@H]1C2=C(C3=C(c4ccccc4)C(=C(c4ccccc4)[C@H]3c3ccccc3)C(c3ccccc3)=C2c2ccccc2)[C@H](c2ccccc2)C1c1ccccc1)C(F)(F)F</smiles>

$( \pm)-9 d$

Figure 6. Postulated Lewis structures of protonated ( \pm )-9. The new proton is marked in red.

At the presence of four equiv. of TFA, selective 1D ${ }^{1} \mathrm{H}$ EXSY NMR measurements show in fact an exchange of the signals at 3.8 and $6.3 \mathrm{ppm}$ with exchange rates of $k_{1}=7.4 \mathrm{~s}^{-1}$ and $k_{2}=-5.1 \mathrm{~s}^{-1}$ (Figure 5). [22]

In the presence of very strong acids, such as $\mathrm{HBF}_{4}$, the solution turns from intense blue to yellow and we were able to observe the di-protonated species 1d (Figure S22 in the SI).

We also recorded electron paramagnetic resonance (EPR) spectra of 1 in $\mathrm{CH}_{2} \mathrm{Cl}_{2}$ in the presence of an excess of TFA. The EPR signal was completely silent and formation of any single electron species can be excluded.

Similarly, acidified solutions of fulvenes $\mathbf{2}$ and $\mathbf{3}$ were analyzed by ${ }^{1} \mathrm{H}$ NMR (see Section S3.2 in the SI). For both, in the presence of 100 equiv. of TFA the spectra nicely fit the structures of $\mathbf{2}$ and $\mathbf{3}$ protonated at $\mathrm{C} 5$ with the new methylene singlet coming in at 4.14 ppm for 2 and 4.25 ppm for 3 (Figures S25 and S28 in the SI).

\section{Theoretical Studies}

In order to better understand the optical spectra as well as the most plausible protonation site(s), we computed optical properties and Gibbs free energies in $\mathrm{CH}_{2} \mathrm{Cl}_{2}$, for the neutral forms of 1, 4, 6, $\mathbf{8}$, and $( \pm)-\mathbf{9}$ and several protonated species. Computations were performed using the Gaussian09 program package ${ }^{[23]}$ and details are found in the Experimental and in Section S8 in the SI.

For fulvene 1, we compared protonation at $\mathrm{C} 2, \mathrm{C} 3, \mathrm{C} 4$, and $\mathrm{C} 5$ (1b), nitrogen (1a), as well as di-protonation (C5 and nitrogen; 1d). Protonation at C5 led to the lowest Gibbs free energy species compared to protonation at the other carbon atoms. $(E)$ to $(Z)$ isomerization of the exocyclic double bond of $\mathbf{1}$ led to higherenergy species, regardless of protonation state.

In C-protonated $\mathbf{1 b}$, the fulvene and phenyl rings are almost in plane with a torsion angle of $3^{\circ}$ whereas for the neutral form 1 the rings are twisted by $21^{\circ}$ (crystal structure; calc: $33^{\circ}$ ) and even more so for $\mathrm{N}$-protonated 1b (torsion angle of $40^{\circ}$ ). As the diprotonated form $\mathbf{1 d}$ again is more planar (torsion angle of $6^{\circ}$ ), protonation at C5 seems to help keeping the torsion angle small. This effect should facilitate $\pi$-conjugation throughout the entire molecule and could explain the experimentally found lower absorption energy of the main transition of dication $1 \mathbf{d}(2.79 \mathrm{eV})$ compared to neutral $1(3.13 \mathrm{eV})$.
Regarding optical spectra, for all protonation sites of 1, except nitrogen, the main absorption band is clearly bathochromically shifted as compared to the neutral form. Protonation at C5 (1) leads to an intense band at $470 \mathrm{~nm}(2.64 \mathrm{eV}, t=1.23, f$ being the oscillator strength). This is significantly lower than the experimental value $(593 \mathrm{~nm} ; 2.09 \mathrm{eV})$. However, the bathochromic shift of the longest-wavelength absorption band upon protonation is in good agreement with the experiment (calculated: $0.95 \mathrm{eV}$; experimental: $1.03 \mathrm{eV}$ ). Besides, the hypsochromic shift of the longest-wavelength absorption band computed for the protonation at nitrogen (1a) is also in fair agreement with experiment (calc. $0.77 \mathrm{eV}$ versus exp. $0.89 \mathrm{eV}$, respectively) supporting the hypothesis of coexistence of these two protonated species upon acidification. For all protonated species, the lowest energy transitions have a HOMO-to-LUMO character. Figure 8 compares frontier orbital lobes of $\mathbf{1}, \mathbf{1 b}$, and 1d. For 1a, the corresponding oscillator strength is low and the lowest-wavelength absorption band mainly involves HOMO-1 and LUMO. On the other hand, for all other computed protonated species, this HOMO-to-LUMO transition contributes most to the longest-wavelength absorption peak. The ranking of the main absorption band is $\lambda_{\max }$ : cation (1a) < neutral $(\mathbf{1})<$ dication $(\mathbf{1 d})<$ cation (1b). This is in full agreement with the experimental findings. The dication $\mathbf{1 d}$ retains a sizeable push-pull character. This can be attributed to the increased planarity of the system as discussed above.

The calculated optical data for compound 4 are consistent with the experimental findings (Figure S35 in the SI). Compared with compound 1, HOMO and HOMO-1 are inverted concomitantly with the character of the first two excitations of compound 4 . Thus, the lowest-energy transition remains weak and the second-lowest corresponds to the main absorption band. Upon protonation, the nature of the HOMO changes (HOMO-1 of the neutral species becomes $\mathrm{HOMO}$ of the cation), which leads to increased oscillator strength of the first excitation and concomitant bathochromic shift. 


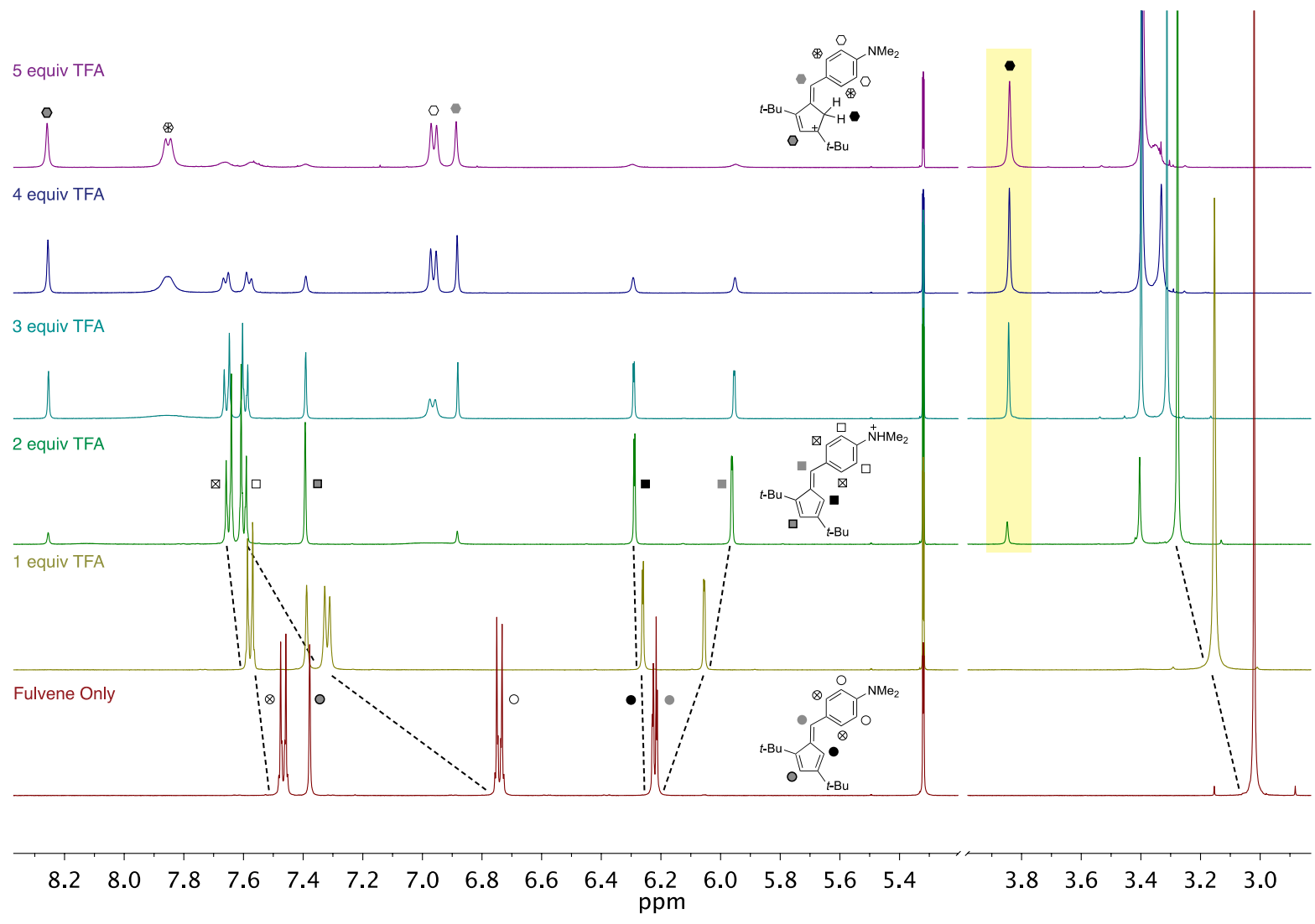

Figure 7. ${ }^{1} \mathrm{H}$ NMR spectra $\left(500 \mathrm{MHz}, \mathrm{T}=298 \mathrm{~K}\right.$ of 1 in pure $\mathrm{CH}_{2} \mathrm{Cl}_{2}$ and after addition of $1,2,3,4$, and 5 equiv. of TFA. Highlighted in yellow is the appearance of the methylene singlet of $\mathrm{C}$-protonated $\mathbf{1 b}$ upon addition of excess TFA.

Similarly, computational results for compound 6 are consistent with experimental findings (Figure S37 in the $\mathrm{SI}$ ) and show a comparable behavior upon protonation. The HOMO-1 of the neutral species becomes the HOMO of the species protonated at C5. In the neutral form, the highest absorption band corresponds to the second excitation that involves mainly an electron redistribution from $\mathrm{HOMO}-1$ to $\mathrm{LUMO}$ and in the protonated form it is the first transition (HOMO-to-LUMO).

Neutral [3]cumulene 8 has a calculated BLA of $0.072 \AA$, which is smaller than the experimental one determined by single-crystal $X$ ray analysis $(0.099 \AA)$. For $\mathbf{8}$, we compared protonation at $\mathrm{C} 2$ and C3 (see Figure 1). Protonation at C3 leads to the lowest Gibbs free energy. Additionally, it leads to an increased BLA of $0.088 \AA$ (compared to the neutral calculated one) indicating an intensified push-pull character. Noteworthy, both protonation sites lead to significant bathochromic shifts of the longest-wavelength absorption band compared to the neutral compound. This shift between the neutral compound and the one protonated at $\mathrm{C} 2$ is in fair agreement with experimental data (calculated: $0.64 \mathrm{eV}$; experimental: $0.75 \mathrm{eV}$ (see above and Figure S39 in the SI)), whereas it is significantly larger $(1.06 \mathrm{eV})$ for protonation at $\mathrm{C} 3$. This is also reflected in $B L A=0.11 \AA$, which is the largest for the C3-protonated form. For the neutral form, the longest-wavelength absorption band corresponds to the third excitation that involves HOMO-2 and LUMO, the lower-intensity transitions having almost vanishing oscillator strength. Upon protonation at C2(C3), HOMO-2 gets destabilized and becomes HOMO-1 (HOMO) of the C2(C3)-protonated form. Thus, the transitions of sizeable oscillator strength keep a similar character and are significantly bathochromically shifted.

The level of theory used herein leads to fair qualitative agreement with experimental data and corroborates that the changes in optical spectra upon acidification are a result of the protonation at C5 (C2 for compound 8) of the fulvene moiety. It should be possible to reach quantitative agreement by implementing state specific corrections for solvent effects, vibronic contributions, and/or considering explicit solvent molecules as well as the dynamic conformational diversity present in solution at room temperature.

\section{Electrochemistry}

Electrochemical investigations of compounds 1 to $( \pm)-9$ were carried out by cyclic voltammetry (CV) and rotating disk voltammetry (RDV) in $\mathrm{CH}_{2} \mathrm{Cl}_{2}$ containing $0.1 \mathrm{M} \mathrm{n}$ - $\mathrm{Bu}_{4} \mathrm{NPF}_{6}$ (Table 1) with and without the addition of TFA. Table $S 1$ in the SI shows all collected data. 
LUMO HOMO HOMO-1 HOMO-2

1

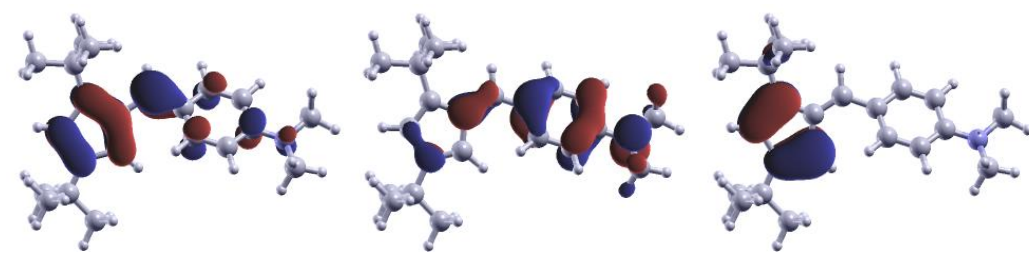

$1 b$
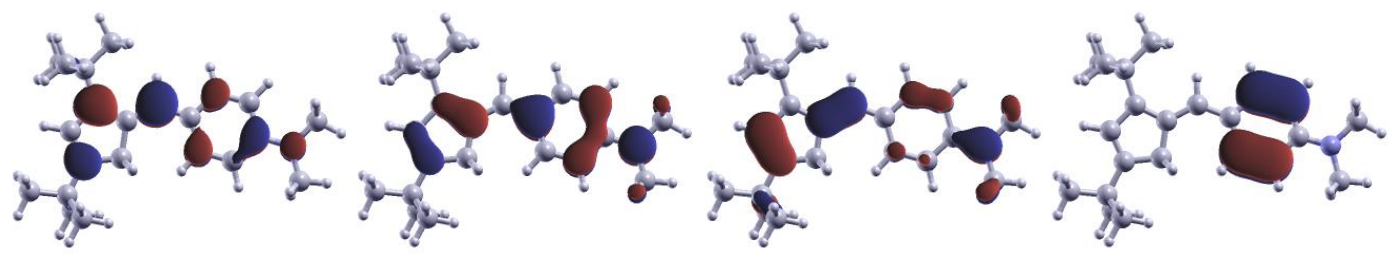

1d
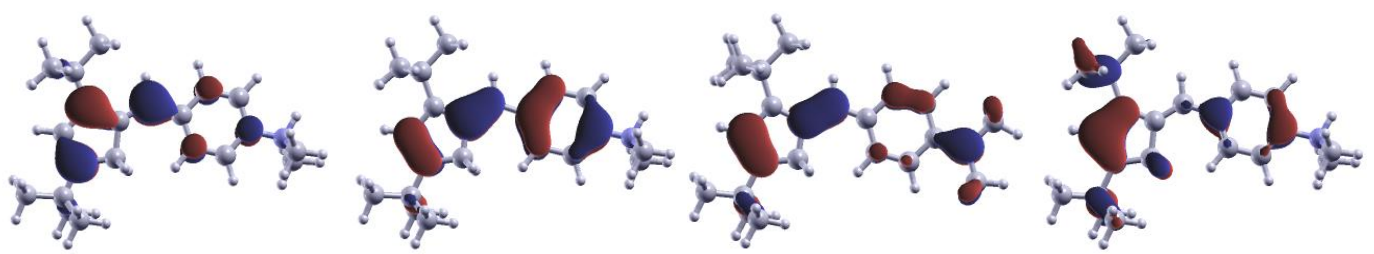

Figure 8. Frontier orbital representations of neutral 1, C5-protonated 1b, and di-protonated $\mathbf{1 d}$.

For all compounds without an amino group, one oxidation step is observed and is usually irreversible. Only compound $\mathbf{5}$ presents one reversible wave at $+0.96 \mathrm{~V}$. In the case of compound $\mathbf{1}$, one reversible one-electron oxidation is detected at $+0.34 \mathrm{~V}$, which is attributed to the oxidation of the amino group, accomplished prior to the oxidation of the fulvene moiety. Furthermore, one or two successive reduction steps are detected. For instance, two successive reversible one-electron reductions are detected for 7 . The first reduction corresponds to the reduction of the $\mathrm{NO}_{2}$ group as previously observed. ${ }^{[24]}$ Furthermore, 6 also presents two successive reductions, however, the second reduction is not reversible. In contrast, only one reduction (one electron exchanged and not reversible) is observed for compounds $\mathbf{4}$ and 5. In contrast, for compounds $\mathbf{1}$ and $\mathbf{2}$, the first reductions are still irreversible but exchanged two electrons.

In the presence of 6 equiv. of TFA, the potentials of the oxidation step do not change much. One exception is $\mathbf{1}$, where the first oxidation at $+0.34 \mathrm{~V}$ (oxidation of the amino group) disappeared due to protonation of the amino group $\left(\mathrm{Me}_{2} \mathrm{NH}^{+}\right)$. In the cathodic part, in acidic media, compounds $\mathbf{1}, \mathbf{2}, \mathbf{3}$, and $\mathbf{8}$ are more easily reduced in one new reduction step (between -0.4 and $-0.8 \mathrm{~V}$ ). The other compounds present one large and irreversible wave at around -1.9 to $-2.2 \mathrm{~V}$.

On the basis of the experimental values, HOMO and LUMO energy levels were estimated. These energy levels lead to HOMO-LUMO gaps in agreement with the optical gaps calculated from the lowest-energy absorption in the UV/Vis spectra. In the presence of TFA, only the four compounds 1, 6, 7, and 8 show experimental values for LUMO and HOMO energy levels comparable to those obtained with the optical spectra. For the four other compounds, one new reduction wave near -0.4 to $-0.8 \mathrm{~V}$ is present. In these cases, the calculation of $E_{\mathrm{OX} 1}-E_{\mathrm{RED} 1}$ (with $E$ being the redox potentials) seems to be inaccurate using the potential of this peak. Finally, the plot of the correlations between the ligand electrochemical parameter (first oxidation and first reduction) and the Hammett substituent parameter $\sigma_{\text {para }}$, as well as the plot of $\left(E_{\mathrm{OX} 1}-E_{\mathrm{RED} 1}\right)$ versus $\sigma_{\text {para }}$ show a linear trend as observed from optical measurement (see Figure S46 in the SI). In acidic media, the same behavior is observed for the first oxidation step under exclusion of compound 1 because of the presence of the protonated $\mathrm{Me}_{2} \mathrm{NH}^{+}$group. It must be noted that, for 7 , the second reduction was used for the linear fit, due to the first reduction being the reduction of the $\mathrm{NO}_{2}$ group. For 1 , the first oxidation potential corresponds to the oxidation of the amino group. Thus, we have used the second potential attributed to the oxidation of the fulvene unit. In this case, a better linear fit is obtained. Figure 9 shows a plot of the first oxidation potential of compounds 1-7 in the presence of TFA versus their Hammett substituent parameter $\sigma_{\text {para }}$. Compound $\mathbf{1}$ is clearly off since it is protonated at the amino group first.

In the case of compound $\mathbf{8}$, two successive one-electron oxidation steps and one-electron reduction steps are detected. In the presence of an excess of TFA, the oxidation waves are observed nearly at the same potential, but in the cathodic region, only one irreversible process is still present at $-0.84 \mathrm{~V}$ versus two successive reduction steps at -0.90 and $-1.17 \mathrm{~V}$ respectively in the absence of TFA. The redox properties of compound ( \pm ) -9 are reported in Section S8 in the SI.

\section{Basicity}

In order to get an insight of the actual quantitative basicity of the investigated fulvenes, $\mathrm{p} K_{\mathrm{a}}$ values of the protonated forms were determined making use of the spectrophotometric method of relative basicity measurements (for details, see Section S6 in the SI). 


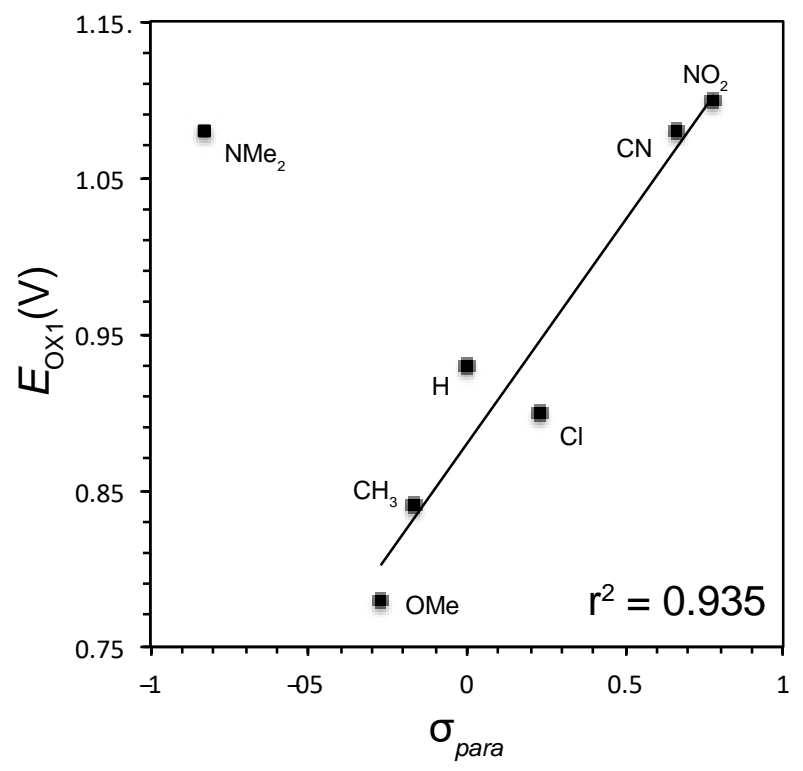

Figure 9. First oxidation potential of compounds $1-7$ in $\mathrm{CH}_{2} \mathrm{Cl}_{2}+6$ equiv. of TFA, plotted against the corresponding Hammett parameters $\sigma_{\text {para. }}$. Compound 1 is excluded from linear regression due to protonation at the amine.

Solubilities of compounds $\mathbf{1}$ to $( \pm)-\mathbf{9}$ are limited to polar organic solvents such as dichloromethane, 1,2-dichloroethane, and acetonitrile. None of the compounds investigated herein are soluble in water or DMSO, which are more popular solvents for $\mathrm{p} K_{\mathrm{a}}$ measurements. ${ }^{[25]}$

We decided to apply the technique of relative measurements which circumvents the need of measuring the acidity of the medium. ${ }^{[26]}$ Where possible, we determined $p K_{a}$ values acetonitrile and $\mathrm{p} K_{\mathrm{ip}}$ (ion-pair basicity) values in 1,2-DCE. The results are shown in Table 1.

Self-consistent basicity scales including weak bases are available in acetonitrile ${ }^{[27 a]}$ in in 1,2-DCE ${ }^{[27 b]}$ and can be used for comparison. Here for measurements in acetonitrile, acceptorsubstituted anilines were used as reference bases. These are very weak bases in acetonitrile. ${ }^{[27,28]}$

For 6 and 7, we estimated $\mathrm{p} K_{\mathrm{a}}$ values in acetonitrile from those in $1,2-D C E$ since their basicity is too low to be measured in acetonitrile. ${ }^{[29]}$ For 6-phenylfulvenes 1-7, experimental $p K_{a}$ values correlate well with $\mathrm{p} K_{\mathrm{a}}$ values calculated based on Hammett parameters of the para-substituents at the phenyl rings (Figure 10).

We were not able to determine the $\mathrm{p} K_{\mathrm{a}}$ value of $\mathbf{8}$ and the second $\mathrm{p} K_{\mathrm{a}}$ value of $\mathbf{1}$ since they both are too low to be measured in the solvents used herein. Due to its instability in solution, $p K_{a}$ measurements of $( \pm)-9$ could not be meaningfully performed.
Table 1. $\mathrm{p} K_{\mathrm{a}}$ values of 6-phenylfulvenes 1-7 measured in acetonitrile and $\mathrm{p} K_{\mathrm{a}}$ values in 1,2DCE.

\begin{tabular}{lll}
\hline Compound & $\mathrm{p} K_{\mathrm{a}}$ in MeCN & $\mathrm{p} K_{\mathrm{a}}$ in 1,2-DCE \\
\hline $\mathbf{1}$ & 10.29 & [a] \\
$\mathbf{2}$ & 4.57 & 6.46 \\
$\mathbf{3}$ & 3.52 & 5.37 \\
$\mathbf{4}$ & 2.93 & 4.50 \\
$\mathbf{5}$ & & \\
$\mathbf{6}$ & 2.58 & 3.83 \\
$\mathbf{7}$ & $1.21^{[\mathrm{b}]}$ & 2.15 \\
\hline
\end{tabular}

[a] Protonates at $\mathrm{NMe}_{2}$. [b] acetonitrile values estimated from 1,2-DCE values (see Section $\mathrm{S} 6$ in the $\mathrm{SI}$ ).

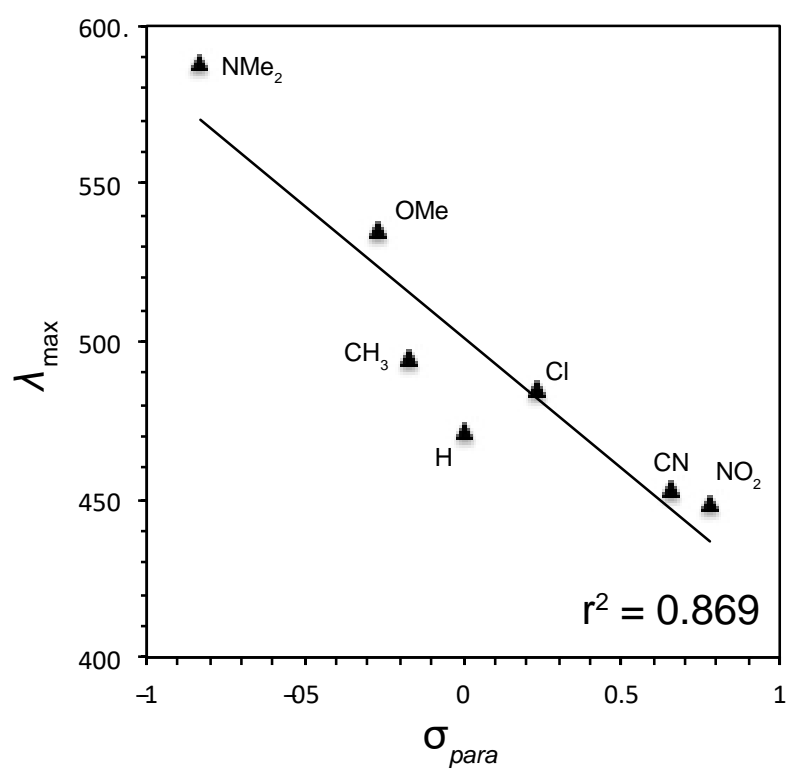

Figure 10. Experimental $\mathrm{p} K_{\mathrm{a}}$ values of 2-7 in MeCN, plotted against predicted $\mathrm{p} K_{\mathrm{a}} \mathrm{s}$ (y axis) by using the multiple correlation formula $\mathrm{p} K_{\mathrm{a}}=\mathrm{p} K_{\mathrm{a} 0}+\mathrm{a}_{\mathrm{F}} \sigma_{\mathrm{F}}+\mathrm{a}_{\mathrm{R}} \sigma$ ${ }_{R}$ where $a_{F}$ and $a_{R}$ are the substituent constants for the resonance effect and the field effect for para-substituents taken from [21].

\section{Conclusions}

Compounds 1-( \pm$)-9$ were successfully synthesized from commercially available starting materials. They showed longerwavelength absorptions upon protonation, as compared to their neutral forms accompanied by visible color changes. The effect is reversed by addition of base. In all cases, NMR studies, UV/Vis spectra, electrochemistry, and theoretical calculations corroborate that protonation takes place at C5 (C2 for compound 
8) of the fulvene ring. The effect of this protonation on optical spectra can be rationalized by (i) effective delocalization of the cationic charge all over the $\pi$-system, (ii) for those molecules that carry electron-donating groups, reinforcement of the push-pull character by enhancement of the electron-withdrawing ability of the protonated fulvene moiety, and (iii) planarization of the 6phenylfulvenes.

The protonation behavior of compound $\mathbf{1}$ is particularly interesting Only at low acid concentration, compound $\mathbf{1}$ is effectively protonated at its dimethyl amino group to form 1a. However, when acid concentration is increased, this form is in equilibrium with the tautomer $\mathbf{1 b}$, which is protonated at C5 and can be drawn as the iminium ion 1e. Additionally, $\mathrm{p} K_{\mathrm{a}}$ values confirm that we are dealing with weak bases with basicities comparable to those of acceptor-substituted anilines. The second $\mathrm{p} K_{\mathrm{a}}$ value of $\mathbf{1}$ is too low to be measured in 1,2-DCE. However, upon addition of much stronger acids such as $\mathrm{HBF}_{4}$, the di-protonated species $\mathbf{1 d}$ can be observed by ${ }^{1} \mathrm{H}$ NMR and UV/Vis spectroscopies.

In this paper, we show that it is possible to protonate the acceptor moiety of a push-pull system when the resulting positive charge is efficiently conjugated throughout the molecule. The study shows that care is advised when assigning charge-transfer bands of push-pull compounds to a specific electronic absorption band based on changes in optical spectra upon acidification. This particular approach only works if the donor is effectively the most basic part of the molecule. Altogether, we presented a new group of $\mathrm{pH}$ sensitive chromophores, whose scope and suitability for future applications in advanced functional materials, $\mathrm{pH}$ sensing, and imaging will be further elaborated in our laboratories.

\section{Experimental Section}

\section{Theoretical Calculations}

Computations were performed using the Gaussian09 program package. ${ }^{[23]}$ All computed structures were characterized through frequency calculations for the verification of minima on the potential energy surface. Geometries were optimized using the $\omega$ B97XD exchange-correlation functional and the $6-31+G^{*}$ basis set in DCM (PCM model). ${ }^{[23]}$ Gibbs free energies were computed at the same level of theory. Optical properties were computed at the TD- $\omega B 97 X D / 6-31+G^{*}$ level of theory in DCM. ${ }^{[30]}$ The bandwidths have been fixed to $0.25 \mathrm{eV}$. For compounds 8 and $( \pm)-9$, we used the $6-31 G^{*}$ basis set for geometries, Gibbs free energies, and optical properties due to convergence issues. Gibbs free energies, frontier orbital representations, and optical properties of all computed structures can be found in Section S8 in the SI.

\section{Synthesis}

\section{4-[(E)-(2,4-Di-tert-butylcyclopenta-2,4-dien-1-ylidene)methyl]- $N, N$ -} dimethylaniline (1). A solution of 1,3-di-tert-butylcyclopenta-1,3-diene 10 $^{[12]}(1.78 \mathrm{~g}, 10 \mathrm{mmol})$ in THF $(50 \mathrm{~mL})$ under nitrogen atmosphere was cooled to $-78{ }^{\circ} \mathrm{C}$, treated with BuLi, $1.6 \mathrm{M}$ in hexane $(6.29 \mathrm{~mL}, 10 \mathrm{mmol})$, stirred at $-78{ }^{\circ} \mathrm{C}$ for $30 \mathrm{~min}$, and treated with 4dimethylaminobenzaldehyde $(1.79 \mathrm{~g}, 12 \mathrm{mmol})$. The mixture was allowed to warm to room temperature over $30 \mathrm{~min}$, stirred at reflux for $12 \mathrm{~h}$, and poured into a saturated aqueous $\mathrm{NH}_{4} \mathrm{Cl}$ solution. The aqueous layer was extracted with $\mathrm{Et}_{2} \mathrm{O}(150 \mathrm{~mL})$. The organic layer was washed with water and brine, dried over $\mathrm{Na}_{2} \mathrm{SO}_{4}$, and evaporated. MPLC (cyclohexane/ $\mathrm{CH}_{2} \mathrm{Cl}_{2}$ ) gave 1 (830 mg, 27\%) as a bright orange solid. M.p. $169{ }^{\circ} \mathrm{C} ;{ }^{1} \mathrm{H}$ NMR $\left(300 \mathrm{MHz}, \mathrm{CDCl}_{3}\right): \delta=1.19\left(\mathrm{~s}, 9 \mathrm{H} ; \mathrm{CMe}_{3}\right), 1.38(\mathrm{~s}, 9 \mathrm{H}$; $\mathrm{CMe}_{3}$ ), 3.02 (s, $6 \mathrm{H} ; \mathrm{NMe}_{2}, 6.19$ (d, $\left.J=1.9 \mathrm{~Hz}, 1 \mathrm{H} ; \mathrm{H}-\mathrm{C}=\mathrm{C}\left(1^{\prime}\right)\right), 6.22$ (dd, $J=2.0,0.8 \mathrm{~Hz}, 1 \mathrm{H} ; \mathrm{H}-\mathrm{C}\left(5^{\prime}\right)$ ), 6.73 (br. d, $J=8.9 \mathrm{~Hz}, 2 \mathrm{H} ; \mathrm{H}-\mathrm{C}(2,5)$ ), 7.38 (br. s, $\left.1 \mathrm{H} ; \mathrm{H}-\mathrm{C}\left(3^{\prime}\right)\right), 7.46 \mathrm{ppm}\left(\mathrm{d}, \mathrm{J}=8.4 \mathrm{~Hz}, 2 \mathrm{H}\right.$; H-C(3,5)); ${ }^{13} \mathrm{C}$ NMR $\left(101 \mathrm{MHz}, \mathrm{CDCl}_{3}\right): \delta=29.75\left(\mathrm{CMe}_{3}\right), 32.44\left(\mathrm{CMe}_{3}\right), 32.68\left(\mathrm{CMe}_{3}\right), 33.32$ $\left(\mathrm{CMe}_{3}\right), 40.39\left(\mathrm{NMe}_{2}\right), 112.11(\mathrm{C}(2,6)), 112.35\left(\mathrm{HC}=\mathrm{C}\left(1^{\prime}\right)\right), 124.91\left(\mathrm{C}\left(5^{\prime}\right)\right)$, 125.60 (C(4)), $132.36(\mathrm{C}(3,5)), 135.67\left(\mathrm{C}\left(3^{\prime}\right)\right), 140.71\left(\mathrm{C}\left(2^{\prime}\right)\right), 147.95$ (C(4')), 150.45 (C(1)), 156.49 ppm (C(1')); IR (ATR): $\tilde{v}=2960(\mathrm{~m}), 2898$ $(\mathrm{m}), 2863(\mathrm{~m}), 1585(\mathrm{~s}), 1521(\mathrm{~s}), 1456(\mathrm{~s}), 1439(\mathrm{~s}), 1358(\mathrm{~s}), 1309(\mathrm{~m})$, $1252(\mathrm{~m}), 1226(\mathrm{~m}), 1161(\mathrm{~s}), 1156(\mathrm{~s}), 1116(\mathrm{~m}), 1089(\mathrm{~m}), 1059(\mathrm{~m})$, $1037(\mathrm{~m}), 1021(\mathrm{~m}), 1008(\mathrm{~m}), 939(\mathrm{~m}), 904(\mathrm{~m}), 880(\mathrm{~m}), 835(\mathrm{~s}), 820(\mathrm{~s})$, $794(\mathrm{~m}), 733(\mathrm{~m}), 655(\mathrm{~s}), 690 \mathrm{~cm}^{-1}(\mathrm{~m}) ; \mathrm{UV} / \mathrm{Vis}\left(\mathrm{CH}_{2} \mathrm{Cl}_{2}\right) \lambda_{\max }(\varepsilon)=300$ (15900), 395 (14900) nm $\left(\mathrm{dm}^{3} \mathrm{~mol}^{-1} \mathrm{~cm}^{-1}\right)$; ESI-MS: $\mathrm{m} / z$ (\%): 310.24834 (24), 309.2448 (100s, [M] ${ }^{+}$, calcd for $\mathrm{C}_{22} \mathrm{H}_{31} \mathrm{~N}$ : 309.24510); elemental analysis calcd (\%) for $\mathrm{C}_{22} \mathrm{H}_{31} \mathrm{~N}$ : C 85.38, H 10.10, N 4.53; found (\%): C 85.47, H 10.22, N 4.26.

General procedure for 6-phenylfulvenes (2-7). Adapted from [11]. A solution of 1,3-di-tert-butylcyclopenta-1,3-diene $\mathbf{1 0}^{[12]}(500 \mathrm{mg}, 2.8 \mathrm{mmol}$, 1 eq) and the aldehyde (4 eq) in $\mathrm{MeOH}(15 \mathrm{~mL})$ was heated to reflux and dropwise treated with a solution of $5 \mathrm{wt} \% \mathrm{NaOMe}(35 \mathrm{~mL}, 30.8 \mathrm{mmol})$ in $\mathrm{MeOH}$ over $30 \mathrm{~min}$. The mixture was stirred at reflux until the starting material 1,3-di-tert-butylcyclopenta-1,3-diene was consumed (monitored by TLC). After evaporation, a solution of the residue in $\mathrm{CH}_{2} \mathrm{Cl}_{2}$ was washed with water two times, dried over $\mathrm{MgSO}_{4}$, and evaporated. Flash column chromatography (hexane/ $\mathrm{CH}_{2} \mathrm{Cl}_{2}$ ) gave the 6-phenylfulvenes 2-7. Their characterization is in Section S2.

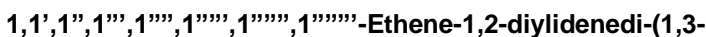

cyclopentadiene-1,2,3,4-tetrayl-5-ylidene)octabenzene (8). A flask was charged with $19(2.13 \mathrm{~g}, 2.64 \mathrm{mmol}), \mathrm{SnCl}_{2}(0.55 \mathrm{~g}, 2.9 \mathrm{mmol})$ and a stir bar. The flask was evacuated and filled with nitrogen three times. After addition of $\mathrm{Et}_{2} \mathrm{O}(25 \mathrm{~mL})$, the solution was treated with $2 \mathrm{M} \mathrm{HCl}$ in $\mathrm{Et}_{2} \mathrm{O}$ $(1.45 \mathrm{~mL}, 2.9 \mathrm{mmol})$, stirred for $4 \mathrm{~h}$ at room temperature, and filtered affording $8(550 \mathrm{mg}, 27 \%)$ as a dark red solid. M.p. $234-236{ }^{\circ} \mathrm{C} ;{ }^{1} \mathrm{H}$ NMR (400 MHz, $\left.\mathrm{CDCl}_{3}\right): 6.64$ (t, $J=7.7 \mathrm{~Hz}, 8 \mathrm{H} ; \mathrm{H}-\mathrm{C}(4)$ of $\left.\mathrm{Ph}\right), 6.77-6.70(\mathrm{~m}$, $8 \mathrm{H} ; \mathrm{H}-\mathrm{C}(4)$ of $\mathrm{Ph}), 6.92-6.80(\mathrm{~m}, 12 \mathrm{H} ; \mathrm{H}-\mathrm{C}(2,3,5,6)$ of $\mathrm{Ph}), 7.17-7.00$ ppm (m, $12 \mathrm{H} ; \mathrm{H}-\mathrm{C}(2,3,5,6)$ of $\mathrm{Ph}) ;{ }^{13} \mathrm{C}$ NMR $\left(101 \mathrm{MHz}, \mathrm{CDCl}_{3}\right): 127.18$ $\left(C\left(4^{\prime}\right)\right), 127.21\left(C\left(4^{\prime}\right)\right), 127.27\left(C\left(2^{\prime}, 6^{\prime}\right)\right), 127.64\left(C\left(2^{\prime}, 6^{\prime}\right)\right), 130.13\left(C\left(3^{\prime}, 5^{\prime}\right)\right)$, $130.28\left(C\left(3^{\prime}, 5^{\prime}\right)\right), 132.62\left(C\left(1^{\prime}\right)\right), 132.67(C(2,5)), 135.04\left(C\left(1^{\prime}\right)\right), 136.57$ $\left(\mathrm{C}\left(1^{\prime}\right)\right), 146.87(\mathrm{C}(3,4)), 161.51 \mathrm{ppm}(\mathrm{C}=\mathrm{C}=\mathrm{C}=\mathrm{C}) ; \mathrm{IR}(\mathrm{ATR}): \tilde{v}=3057(\mathrm{w})$, 2835 (very w), 1596 (w), 1573 (very w), $1483(w), 1439(w), 1338(w), 1280$ (very w), $1230(\mathrm{~m}), 1180(\mathrm{w}), 1110(\mathrm{w}), 1070(\mathrm{w}), 1028(\mathrm{w}), 1004(\mathrm{w}), 977$ $(w), 917(w), 907(w), 842(w), 803(w), 760(m), 747(m), 725$ (very w), $691(\mathrm{~s}), 669(\mathrm{~m}), 641 \mathrm{~cm}^{-1}(\mathrm{w})$; UV/Vis $\left(\mathrm{CH}_{2} \mathrm{Cl}_{2}\right) \lambda_{\max }(\varepsilon)=505 \mathrm{~nm}(53700$ $\mathrm{dm}^{3} \mathrm{~mol}^{-1} \mathrm{~cm}^{-1}$ ); MALDI-MS: $\mathrm{m} / z$ (\%): 762.3191 (20), 761.3156 (65), $760.3123\left(100,[M]^{+}\right.$calcd for $\left.\mathrm{C}_{60} \mathrm{H}_{40} 0^{+}: 760.3125\right)$; elemental analysis calcd (\%) for $\mathrm{C}_{60} \mathrm{H}_{40}$ : C 94.70, H 5.30; found (\%): C 78.37, H 4.86 .

Racemic mixture of $(2 R, 3 S, 6 \mathrm{a} R, 7 R)-2,4,5,6,6 \mathrm{a}, 7-$ Hexaphenyl-1(2,3,4,5-tetraphenylcyclopenta-2,4-dien-ylidene)-2,3,6a,7-tetrahydro$1 \mathrm{H}$-cyclopenta[a]pentalen-3-yl trifuoroacetate and enantiomer (( \pm )-9). A flask was charged with $21(1.13 \mathrm{~g}, 2.2 \mathrm{mmol})$ and a stir bar. The flask was evacuated and filled with nitrogen three times. $\mathrm{CH}_{2} \mathrm{Cl}_{2}(50 \mathrm{~mL})$ and then TFA $(0.84 \mathrm{~mL}, 11 \mathrm{mmol})$ were added. The mixture was stirred at room temperature for $1 \mathrm{~h}$ (monitored by TLC hexane/EtOAc 9:1) and poured onto a sat. $\mathrm{NaHCO}_{3}$ solution. After separation of the layers, the aqueous layer was extracted with $\mathrm{CH}_{2} \mathrm{Cl}_{2}$ three times. The combined organic layers were washed with $\mathrm{H}_{2} \mathrm{O}$ and brine, dried over $\mathrm{MgSO}_{4}$, and evaporated. Flash column chromatography (hexane/EtOAc) gave ( \pm )-9 (391 mg, 33\%) as a dark pink solid. M.p. $210^{\circ} \mathrm{C} ;{ }^{1} \mathrm{H}$ NMR $\left(600 \mathrm{MHz}, \mathrm{CDCl}_{3}\right): 3.64(\mathrm{~d}, J=$ $1.4 \mathrm{~Hz} 1 \mathrm{H}, \mathrm{H}-\mathrm{C}(2)), 4.30(\mathrm{~s}, 1 \mathrm{H}, \mathrm{H}-\mathrm{C}(7)), 5.47(\mathrm{~d}, J=1,4 \mathrm{~Hz}, 1 \mathrm{H}, \mathrm{H}-$ $\mathrm{C}(3)), 7.24-6.34 \mathrm{ppm}(\mathrm{m}, 50 \mathrm{H}, \mathrm{H}-\mathrm{C}(2,3,4,5,6)$ of $10 \mathrm{Ph}) ;{ }^{13} \mathrm{C}$ NMR $(151$ 
$\left.\mathrm{MHz}, \mathrm{CDCl}_{3}\right): 56.18$ and $60.35(\mathrm{C}(2,7)), 80.46$ and $82.27(\mathrm{C}(3,6 \mathrm{a}), 125.89$ and $126.06\left(\mathrm{CF}_{3}\right), 126.69(\mathrm{C}-\mathrm{H}$ of $\mathrm{Ph}), 126.71(\mathrm{C}-\mathrm{H}$ of $\mathrm{Ph}), 126.78(\mathrm{C}-\mathrm{H}$ of $\mathrm{Ph}), 126.87(\mathrm{C}-\mathrm{H}$ of $\mathrm{Ph}), 126.92(\mathrm{C}-\mathrm{H}$ of $\mathrm{Ph}), 127.09(\mathrm{C}-\mathrm{H}$ of $\mathrm{Ph})$, $127.13(\mathrm{C}-\mathrm{H}$ of $\mathrm{Ph}), 127.14(\mathrm{C}-\mathrm{H}$ of $\mathrm{Ph}), 127.31(\mathrm{C}-\mathrm{H}$ of $\mathrm{Ph}), 127.32(\mathrm{C}-$ $\mathrm{H}$ of $\mathrm{Ph}), 127.94(\mathrm{C}-\mathrm{H}$ of $\mathrm{Ph}), 128.04(\mathrm{C}-\mathrm{H}$ of $\mathrm{Ph}), 128.10(\mathrm{C}-\mathrm{H}$ of $\mathrm{Ph})$, $128.12(\mathrm{C}-\mathrm{H}$ of $\mathrm{Ph}), 128.17(\mathrm{C}-\mathrm{H}$ of $\mathrm{Ph}), 128.18(\mathrm{C}-\mathrm{H}$ of $\mathrm{Ph}), 128.22(\mathrm{C}-$ $\mathrm{H}$ of $\mathrm{Ph}), 128.28(\mathrm{C}-\mathrm{H}$ of $\mathrm{Ph}), 128.65(\mathrm{C}-\mathrm{H}$ of $\mathrm{Ph}), 128.67(\mathrm{C}-\mathrm{H}$ of $\mathrm{Ph})$, $129.83(\mathrm{C}-\mathrm{H}$ of $\mathrm{Ph}), 130.16(\mathrm{C}-\mathrm{H}$ of $\mathrm{Ph}), 130.25(\mathrm{C}-\mathrm{H}$ of $\mathrm{Ph}), 130.55(\mathrm{C}-$ $\mathrm{H}$ of $\mathrm{Ph}$ ), 131.30 (C quart), 131.60 (C quart), 131.69 ( $\left.\mathrm{C}_{\text {quart }}\right), 133.16$ (C quart), 134.53 ( $\mathrm{C}_{\text {quart }}$ ), 135.23 ( $\left.\mathrm{C}_{\text {quart }}\right), 135.59$ ( $\left.\mathrm{C}_{\text {quart }}\right), 136.10$ ( $\left.\mathrm{C}_{\text {quart }}\right), 136.13$ ( $\left.\mathrm{C}_{\text {quart }}\right), 138.25$ ( $\left.\mathrm{C}_{\text {quart }}\right), 138.51$ ( $\left.\mathrm{C}_{\text {quart }}\right), 139.91$ ( $\left.\mathrm{C}_{\text {quart }}\right), 141.32$ ( $\left.\mathrm{C}_{\text {quart }}\right)$, $141.81(\mathrm{C}(1)$ of $\mathrm{Ph}), 142.31(\mathrm{C}(1)$ of $\mathrm{Ph}), 144.15(\mathrm{C}(1)$ of $1 \mathrm{Ph}), 144.58$ $(\mathrm{C}(1)$ of $1 \mathrm{Ph}), 144.85(\mathrm{C}(1)$ of $1 \mathrm{Ph}), 148.28(\mathrm{C}(1)$ of $1 \mathrm{Ph}), 150.08(\mathrm{C}(1)$ of $1 \mathrm{Ph}), 151.71(\mathrm{C}(1)$ of $1 \mathrm{Ph}), 151.78(\mathrm{C}(1)$ of $1 \mathrm{Ph}), 152.13\left(\mathrm{CO}_{2} \mathrm{CF}_{3}\right)$, $169.49 \mathrm{ppm}(\mathrm{C}(1)$ of $1 \mathrm{Ph}) ;{ }^{19} \mathrm{~F} \mathrm{NMR}\left(282 \mathrm{MHz}, \mathrm{CDCl}_{3}\right):-74.18 \mathrm{ppm}$; IR (ATR): $\tilde{v}=3056(w), 3026(w), 1779(m, C=O ~ s t), 1713(w) 1598(w), 1492$ $(\mathrm{m}), 1441(\mathrm{~m}), 1402(\mathrm{w}), 1316(\mathrm{w}) ; 1260(\mathrm{w}), 1220(\mathrm{~m}), 1170(\mathrm{~m}), 1142$ $(\mathrm{m}), 1072(\mathrm{~m}), 1027(\mathrm{~m}), 1002(\mathrm{w}), 920(\mathrm{w}), 840(\mathrm{w}), 803(\mathrm{w}), 751(\mathrm{~m}) 751$ $(\mathrm{m}), 693(\mathrm{~s}) \mathrm{cm}^{-1}$; UV/Vis $\left(\mathrm{CH}_{2} \mathrm{Cl}_{2}\right) \lambda_{\max }(\varepsilon)=540(13300), 358(8970) \mathrm{nm}$ (dm $\mathrm{dmol}^{-1} \mathrm{~cm}^{-1}$ ); MALDI-MS: $\mathrm{m} / z$ (\%): 1080.4058 (34), 1079.4024 (83, [M $+\mathrm{H}^{+}$, calcd for $\mathrm{C}_{78} \mathrm{H}_{54} \mathrm{~F}_{3} \mathrm{O}_{2}{ }^{+}:$1079.4070), $1078.3990\left(100,\left[\mathrm{M}^{+}\right.\right.$, calcd for $\mathrm{C}_{78} \mathrm{H}_{53} \mathrm{~F}_{3} \mathrm{O}_{2}{ }^{+}:$1078.3992), $965.4127\left(26,\left[M-\mathrm{C}_{2} \mathrm{~F}_{3} \mathrm{O}_{2}\right]^{+}\right.$, calcd for $\mathrm{C}_{76} \mathrm{H}_{53}{ }^{+}$: 965.4142), elemental analysis calcd (\%) for $\mathrm{C}_{78} \mathrm{H}_{53} \mathrm{O}_{2} \mathrm{~F}_{3}$ : C 86.80, $\mathrm{H} 4.95$, O 2.96, F 5.28; found (\%): C 86.85, H 5.10, F 3.00 .

\section{Acknowledgements}

This work was supported by the Swiss National Science Foundation (SNF 200020_159802). The authors thank Dr. Bruno Bernet for assistance in the spectral evaluations as well as René Arnold and Dr. Marc-Olivier Ebert for recording selective 1D EXSY NMR spectra.

Keywords: Fulvenes • Fulvalenes • Cumulenes • Carbocations • Push-Pull Chromophores

[1] B. Halton, Eur. J. Org. Chem. 2005, 3391-3414.

[2] H. Prinzbach, D. Seip, L. Knothe, W. Faisst, Liebigs Ann. Chem. 1966, 698, 34-56.

[3] a) C. Rentsch, M. Slongo, M. Neuenschwander, Makromol. Chem. 1978, 179, 1647-1648; b) C. Rentsch, M. Slongo, S. Schönholzer, M. Neuenschwander, Makromol. Chem. 1980, 181, 19-29; c) M. Slongo, S. Schönholzer, C. Rentsch, M. Neuenschwander, Makromol. Chem. 1980 181, 31-36; d) S. Schönholzer, M. Slongo, C. Rentsch, M. Neuenschwander, Makromol. Chem. 1980, 181, 37-45; e) P. Kronig, M. Slongo, M. Neuenschwander, Makromol. Chem. 1982, 183, 359-375.

[4] G. A. Olah, G. Prakash, G. Liang, J. Org. Chem. 1977, 42, 661-666.

[5] A. W. Jasper, N. Hansen, Proc. Combust. Inst. 2013, 34, 279-287.

[6] I. Garkusha, J. Fulara, A. Nagy, J. P. Maier J. Am. Chem. Soc. 2010, 132, 14979-14985.

[7] A. S. Kende, P. T. Izzo, J. Am. Chem. Soc. 1965, 87, 1609-1610

[8] S. Achelle, J. Rodríguez-López, C. Katan, F. Robin-le Guen J. Phys. Chem. C 2016, 120, 26986-26995.

[9] a) N. N. P. Moonen, W. C. Pomerantz, R. Gist, C. Boudon, J.-P. Gisselbrecht, T. Kawai, A. Kishioka, M. Gross, M. Irie, F. Diederich, Chem. Eur. J. 2005, 11, 3325-3341; b) T. Michinobu, C. Boudon, J.-P. Gisselbrecht, P. Seiler, B. Frank, N. N. P. Moonen, M. Gross, F. Diederich, Chem. Eur. J. 2006, 12, 1889-1905; c) M. Kivala, C. Boudon, J.-P. Gisselbrecht, B. Enko, P. Seiler, I. B. Müller, N. Langer, P. D. Jarowski, G. Gescheidt, F. Diederich, Chem. Eur. J. 2009, 15, 41114123; d) G. Jayamurugan, O. Dumele, J.-P. Gisselbrecht, C. Boudon, W.
B. Schweizer, B. Bernet, F. Diederich, J. Am. Chem. Soc. 2013, 135 3599-3606.

[10] a) F. G. Bordwell, J.-P. Cheng, G.-Z. Ji, A. V. Satish, X. Zhang, J. Am Chem. Soc. 1991, 113, 9790-9795

[11] D. Braun, R. Langendorf, J. Prakt. Chem. 2000, 342, 80-82.

[12] C. E. Zachmanoglou, J. G. Melnick, B. M. Bridgewater, D. G. Churchill, G. Parkin, Organometallics, 2005, 24, 603-611.

[13] (Z)-Configured products were not isolated, but their formation cannot be excluded since reaction byproducts were not investigated further. They should however be disfavored due to steric repulsion between the phenyl ring and the tert-butyl group at $\mathrm{C} 2$.

[14] J. R. Johnson, O. Grummitt, Org. Synth. 1943, 23, 92.

[15] a) L. Leroyer, V. Maraval, R. Chauvin, Chem. Rev. 2012, 112, 1310 1343; b) J. A. Januszewski, R. R. Tykwinski, Chem. Soc. Rev. 2014, 43, 3184-3203.

[16] BLA in cumulenes is reported as the (average) difference in the bond length between the two central-most bonds of the cumulene chain; see: a) J. A. Januszewski, D. Wendinger, C. D. Methfessel, F. Hampel, R. R. Tykwinski, Angew. Chem. Int. Ed. 2013, 52, 1817-1821; Angew. Chem. 2013, 125, 1862-1867; b) P. Gawel, Y.-L. Wu, A. D. Finke, N. Trapp, M. Zalibera, C. Boudon, J.-P. Gisselbrecht, W. B. Schweizer, G. Gescheidt, F. Diederich, Chem. Eur. J. 2015, 21, 6215-6225.

[17] D. Wendinger, R. R. Tykwinski, Acc. Chem. Res. 2017, 50, 1468-1479.

[18] M. Tommasini, A. Milani, D. Fazzi, A. Lucotti, C. Castiglioni, J. A Januszewski, D. Wendinger, R. R. Tykwinski, J. Phys. Chem. C 2014, 118, 26415-26425.

[19] a) E. A. Meyer, R. K. Castellano, F. Diederich, Angew. Chem. Int. Ed. 2003, 42, 1210-1250; Angew. Chem. 2003, 115, 1244-1287; b) M. O Sinnokrot, C. D. Sherrill, J. Phys. Chem. A 2004, 108, 10200-10207.

[20] The different amount of TFA needed to fully form the protonated 6phenylfulvenes qualitatively correlates with the pKa values; the more basic, the less excess of TFA is needed. We also note that in the NMR titrations, less TFA is needed to form the protonated species. The deuterated solvents for these titrations apparently are dryer than the dichloromethane (HPLC grade, without special drying) used for the UV/Vis spectra.

[21] C. Hansch, A. Leo, R. W. Taft, Chem. Rev. 1991, 91, 165-195.

[22] I. Pochorovski, M.O. Ebert, J.-P. Gisselbrecht, C. Boudon, W. B. Schweizer, F. Diederich J. Am. Chem. Soc. 2012, 134, 14702-14705.

[23] M. J. Frisch, G. W. Trucks, H. B. Schlegel, G. E. Scuseria, M. A. Robb, J. R. Cheeseman, G. Scalmani, V. Barone, B. Mennucci, G. A. Petersson, H. Nakatsuji, M. Caricato, X. Li, H. P. Hratchian, A. F. Izmaylov, J. Bloino, G. Zheng, J. L. Sonnenberg, M. Hada, M. Ehara, K. Toyota, R. Fukuda, J. Hasegawa, M. Ishida, T. Nakajima, Y. Honda, O. Kitao, H. Nakai, T. Vreven, J. A. Montgomery, Jr., J. E. Peralta, F. Ogliaro, M. Bearpark, J. J. Heyd, E. Brothers, K. N. Kudin, V. N. Staroverov, R. Kobayashi, J. Normand, K. Raghavachari, A. Rendell, J. C. Burant, S. S. lyengar, J. Tomasi, M. Cossi, N. Rega, J. M. Millam, M. Klene, J. E. Knox, J. B. Cross, V. Bakken, C. Adamo, J. Jaramillo, R. Gomperts, R. E. Stratmann, O. Yazyev, A. J. Austin, R. Cammi, C. Pomelli, J. W. Ochterski, R. L. Martin, K. Morokuma, V. G. Zakrzewski, G. A. Voth, P. Salvador, J. J Dannenberg, S. Dapprich, A. D. Daniels, Ö. Farkas, J. B. Foresman, J. V. Ortiz, J. Cioslowski, and D. J. Fox, Gaussian 09, Revision D.01, Gaussian, Inc., Wallingford CT, 2013.

[24] A. Hilger, J.-P. Gisselbrecht, R. R. Tykwinski, C. Boudon, M. Schreiber, R. E. Martin, H. P. Lüthi, M. Gross, F. Diederich, J. Am. Chem. Soc. 1997 119, 2069-2078.

[25] F. G. Bordwell Acc. Chem. Res. 1988, 21, 456-463.

[26] a) A. Kütt, T. Rodima, J. Saame, E. Raamat, V. Mäemets, I. Kaljurand, I. A. Koppel, R. Y. Garlyauskayte, Y. L. Yagupolskii, L. M. Yagupolskii, E. Bernhardt, H. Willner, I. Leito, J. Org. Chem. 2011, 76, 391-395; b) M. Zhang, T. Sonoda, M. Mishima, T. Honda, I. Leito, I. A. Koppel, W. Bonrath, T. Netscher, J. Phys. Org. Chem. 2014, 27, 676-679. 
[27] a) K. Haav, J. Saame, A. Kütt, I. Leito Eur. J. Chem. 2012, 2167-2172 b) K. Kaupmees, R. Järviste, I. Leito, Chem. Eur. J. 2016, 22, 1744517449.

[28] Examples for reference bases: 2- $\mathrm{NO}_{2}$-aniline $\left(\mathrm{p} \mathrm{K}_{\mathrm{a}, \mathrm{MeCN}}=4.80\right), 5-\mathrm{Cl}-2$ $\mathrm{NO}_{2}$-aniline $\left(\mathrm{p} K_{\mathrm{a}, \mathrm{MeCN}}=3.22\right)$, 4- $\mathrm{NO}_{2}$-aniline $\left(\mathrm{p} K_{\mathrm{a}, \mathrm{MeCN}}=6.22\right), 2,3,4,5,6$ $\mathrm{Cl}_{5}$-aniline $\left(\mathrm{p} K_{\mathrm{a}, \mathrm{MeCN}}=2.53\right)$.
[29] E. Raamat, K. Kaupmees, G. Ovsjannikov, A. Trummal, A. Kütt, J. Saame, I. Koppel, I. Kaljurand, L. Lipping, T. Rodima, V. Pihl, I. A. Koppel, I. Leito J. Phys. Org. Chem. 2013, 26, 162-170.

[30] J. Tomasi, B. Mennucci, R. Cammi, Chem. Rev. 2005, 105, 2999-3093. 
Acid-induced protonation of novel fulvenes and fulvalenes under ambient conditions leads to the formation of stable carbocations with unusual absorption spectra having bathochromcially shifted longestwavelength absorptions as compared to their neutral forms.

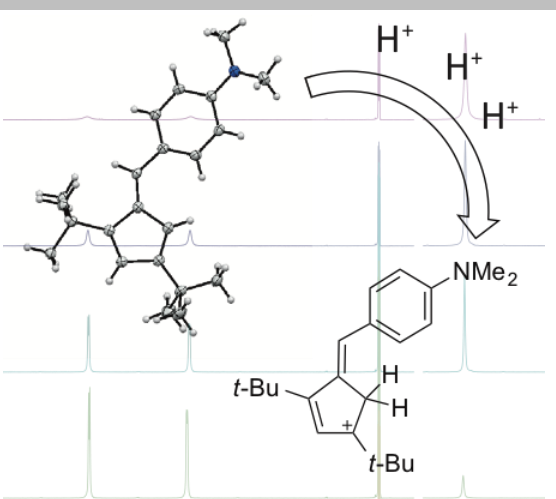

Sophie Haberland, Dr. Aaron D. Finke, Dr. Nicolas Kerisit, Dr. Claudine Katan, Dr. Yann Trolez, Dr. Przemyslaw Gawel, Prof. Ivo Leito, Märt Lõkov, Robert Järviste, Dr. Karl Kaupmees, Dr. Nils Trapp, Prof. Laurent Ruhlmann, Prof. Corinne Boudon, Dr. Daniel Himmel and Prof. François Diederich* $^{*}$

Page No. - Page No.

Enhancement of Push-Pull Properties of Pentafulvene and Pentafulvalene Derivatives by

Protonation at Carbon 